\title{
Effect of Indomethacin on the Pregnant Rat
}

\author{
Débora Cristina Damasceno $^{1}$, Gustavo Tadeu Volpato $^{1}$, Cássio Ferrari $^{2}$, Luciana B. \\ Roldan $^{2}$ and Maricelma da Silva Soares Souza ${ }^{3}$ \\ ${ }^{1}$ Laboratório de Pesquisa Experimental de Ginecologia e Obstetrícia; Departamento de Ginecologia e Obstetrícia; \\ Faculdade de Medicina de Botucatu; Universidade Estadual Paulista; damasceno@fmb.unesp.br; Distrito de \\ Rubião Jr., s/n; 18618-000; Botucatu - SP - Brasil. ${ }^{2}$ Faculdade de Medicina de Marilia; ${ }^{3}$ Disciplina de \\ Farmacologia; Universidade de Marilia; Marília - SP - Brasil
}

\begin{abstract}
The objective of this study was to evaluate the reproductive performance, liver morphological study and post mortem characteristics of the pregnant Wistar rats treated with indomethacin, a general COX inhibitor. Indomethacin at doses of 0 (control), 0.32, 1.68 and $8.40 \mathrm{mg} / \mathrm{kg} /$ day were orally given once daily to each group $(n=10)$ on days 3 and 4 of pregnancy (day $0=$ first day of pregnancy = positive vaginal sperm). The animals were euthanized under anesthesia on day 11 of pregnancy, and were carried out necropsy and microorganism culture study. The results showed that the doses of 0.32 and $1.68 \mathrm{mg} / \mathrm{kg}$ body weight (the therapeutic dose for humans) of indomethacin caused no embryotoxic or lethal effects. The highest dose $(8.40 \mathrm{mg} / \mathrm{kg})$ of indomethacin disturbed implantation process and, thus, interrupted major development in some fetuses. The peritonitis was detected in the necropsy and in the bacteriological study of the animals treated with $8.4 \mathrm{mg} / \mathrm{kg}$. It was considered death cause of these animals. Thus, this study analyzed a pharmacological agent on pregnancy in rodents and it provided some evidences that indomethacin presented embryotoxic and lethal effects at a high dose, but it was safe in the therapeutic dose used for humans.
\end{abstract}

Key words: Indomethacin, COX, pregnancy, rat, implantation

\section{INTRODUCTION}

The effective reciprocal interaction between the implantation-competent blastocyst and the receptive uterus is one of the prerequisites for mammalian reproduction. This at the molecular and cellular level is very important for embryo implantation (Tranguchi et al., 2005). The processes essential to implantation include synchronized preimplantation embryo development to the blastocyst stage, escape of the blastocyst from the zona pelucida, and differentiation of the uterus to the receptive state (Moore and Persaud, 2005). The processes of ovulation and implantation are considered analogous to the proinflammatory responses, hence, the speculation that prostaglandins (PGs) play a role in these events. Specifically, PGs play a role during endometrial vascular permeability during implantation and decidualization.

Prostaglandins produced by the activity of cyclooxygenases (COX) are involved in various processes associated with reproduction. COX exists in two isoforms, COX-1 and COX-2. COX1 is expressed in uterine luminal and glandular epithelial cells on the morning at day 4 of pregnancy, but its expression becomes very low to undetectable in epithelial cells by the time of the attachment reaction. In contrast, COX-2 is expressed in the luminal epithelium and

\footnotetext{
${ }^{*}$ Author for correspondence
} 
underlying stromal cells solely at the site of blastocyst attachment. This suggests that COX-2 expression during the attachment reaction is crucial to implantation (Chakraborty et al., 1996). COX inhibitors, nonsteroidal antiinflammatory drugs (NSAIDs) used worldwide, inhibit PG syntesis (Dannhardt and Kiefer, 2001). Indomethacin is a NSAID drug, a nonselective COX-1/COX-2 inhibitor, used to treat several rheumatologic disorders (Sookvanichsilp and Pulbutr, 2002). It presents a property less aggressive than the hormonal anti-inflammatory drugs.

Previous studies have shown that indomethacin at $3 \mathrm{mg} / \mathrm{kg} / \mathrm{twice}$ a day dose administered on days 35 of rat pregnancy (Poyser, 1999) and 5 $\mathrm{mg} / \mathrm{kg} /$ day, administered on the similar period, reduced the number of implantation sites, and at $10 \mathrm{mg} / \mathrm{kg} /$ day dose caused severe gastrointestinal bleeding and animal death (Sookvanichsilp and Pulbutr, 2002). Preimplantation and postimplantation losses were significantly increased at $10 \mathrm{mg} / \mathrm{kg} /$ day of indomethacin (Shafiq et al., 2004). However, Kennedy (1977) found no significant effect of indomethacin at a dose of $1 \mathrm{mg} / \mathrm{rat} / \mathrm{twice}$ on day 5 of pregnancy on the proportion of animals with uterine dye sites on day 6 of pregnancy. There was no evidence of death caused in the animals treated with indomethacin. The present study was designed to evaluate the reproductive performance data, liver morphological studies and post mortem characteristics (by necropsy and microorganism culture study) in the pregnant rats treated with indomethacin.

\section{MATERIALS AND METHODS}

\section{Animals}

Female and male Wistar rats weighing $200 \pm 20 \mathrm{~g}$ were used. The rats were kept in a controlled room $\left(22 \pm 3^{\circ} \mathrm{C}\right)$ under a 12-h light/dark cycle (light on/off at 7 A.M./ 7 P.M., respectively), with free access to commercial pellets diet (Purina ${ }^{\circledR}$ rat chow) and tap water. They were allowed to acclimatize for one week before experiments were started. All the experiments were conducted after obtaining approval from the Ethics Committee of Medicine School of São Paulo State University (Unesp). Virgin female Wistar rats were mated overnight with adult male Wistar rats. Vaginal smears were taken daily and examined microscopically, and on the next morning when sperm were found in the vaginal smear was designated day 0 of pregnancy. Mated females assigned at random to four groups ( $\mathrm{n}=10$ rats) and were maintained in separate cages.

\section{Chemicals and dosing}

Indomethacin (obtained from a $25 \mathrm{mg}$ capsule) at $0.32,1.68$ and $8.40 \mathrm{mg} / \mathrm{kg} /$ day doses were administered by intragastric route (gavage) once daily to each group on days 3 and 4 of pregnancy. The control group received equal volume of vehicle on days 3 and 4 of pregnancy.

\section{Food intake and maternal weight evaluations}

Food consumption and the maternal weight were measured daily in the morning (9 A.M.) during the pregnancy.

\section{Laparotomy on day 11 of pregnancy}

On day 11 day of pregnancy, the rats were anaesthetized with ether overdose and subjected to the examination. After anesthesia, the uterine horns were removed and the number and distribution of implantation sites and embryos in development were recorded. The ovaries of the rats were observed and the corpora lutea were also counted. To confirm the embryonic implantation sites, the uterine horns were placed in Salewski reactive (Salewski, 1964). The preimplantation loss was obtained by following ratio: number of corpora lutea - number of implantation sites / number of corpora lutea. The postimplantation loss rate was calculated as: number of implantation sites - number of embryos developed / number of implantation sites (Damasceno et al., 2002). The lethality rate was calculated as: number of death female / number of female mated. The pregnancy rate was obtained by number of pregnant at term / number of female mated (Clegg et al., 2001).

\section{Liver morphological analysis}

Maternal liver samples from 4 rats/group were removed, fixed in Bouin's solution for $24 \mathrm{~h}$ at room temperature, dehydrated and embedded in paraffin. Thick sections of $7 \mu \mathrm{m}$ were stained with Haematoxylin-Eosin (HE) for morphological analysis.

\section{Microorganism culture study}

For the bacteriological study of post mortem animals, the sterile swabs were passed over the 
parietal peritoneal surface and then plated. The colon area was aseptically dissected, removed and liquefied in sterile saline for aerobic cultures. After dilution, samples were cultured in aerobic medium and incubated at $37^{\circ} \mathrm{C}$ for quantitative bacterial count at $48 \mathrm{~h}$. Total aerobic and anaerobic bacterial counts were made by incubating the plates for 3 days at $37^{\circ} \mathrm{C}$ under aerobic and anaerobic conditions, respectively. Further identification of gram-negative anaerobes, lactobacilli and others were performed using appropriate culture media.

\section{Data analysis}

The litter was considered an experimental unit. Mean \pm standard deviation (SD) of the initial body weight, body weight gain and food consumption of pregnant rats, numbers of implantations, corpora lutea, and embryos were calculated. For comparions, analysis of variance (ANOVA) followed by Student Newman Keuls test was used. Percentage of died and at term pregnant rats, pre and postimplantation loss rates were compared by Fisher test (Zar, 1999). $p<0.05$ was considered significant.

\section{RESULTS}

\section{Food intake and maternal weight evaluations}

There was a significant decrease in the food consumption and in maternal weight from day 6 to 11 of pregnancy in the rats treated with 8.40 $\mathrm{mg} / \mathrm{kg}$ of indomethacin (Figs. 1 and 2).

\section{Laparotomy on day 11 of pregnancy - reproductive performance data}

The group of rats treated with indomethacin at a dose of $8.40 \mathrm{mg} / \mathrm{kg}$ presented two rats dead from
15 rats mated, and from the 13 pregnant rats remaining two did not develop at term pregnancy. A significant increase in the preimplantation loss and a reduction in the embryo numbers were observed at $8.40 \mathrm{mg} / \mathrm{kg}$. The lower doses ( 0.32 and $1.68 \mathrm{mg} / \mathrm{kg}$ ) caused no death and there was not significant difference on the reproductive performance parameters compared to control group (Tab. 1).

\section{Liver morphological analysis}

The light microscopy analysis of maternal liver samples from the rats treated with $0 \mathrm{mg} / \mathrm{kg}$ (control), 0.32 , and $1.68 \mathrm{mg} / \mathrm{kg}$ of indomethacin showed typical structural organization, normal central veins, many binucleated hepatocytes and absence of inflammatory infiltrated. The liver morphological analysis of the rats that received the highest dose of the drug showed an alteration in the Glisson's capsule. The classical hepatic lobule presented a normal structure and central vein, minimal inflammatory infiltrated in the portal triad and microvacuolization of hepatocytes.

\section{Post mortem examination and microorganism culture study}

The post-mortem analysis in the two female rats treated with the highest dose showed colon ulcer formation. The culture of microorganisms revealed presence of Escherichia coli in the peritoneal liquid and intestinal content in the animals of this group. The same rats also presented the intestinal loops adhered to the uterine horns, which impaired the embryonic analysis and implantation number counting. 


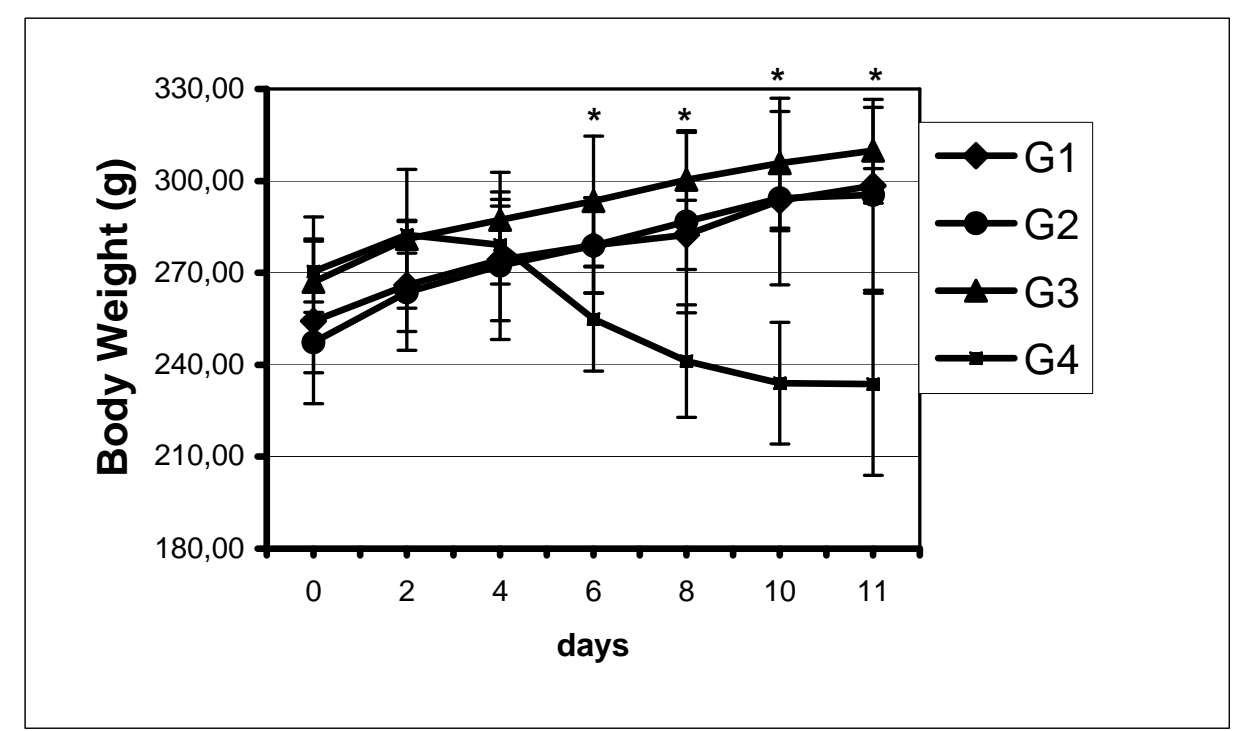

Legend: $\mathrm{G} 1=0 \mathrm{mg} / \mathrm{kg}$ of indomethacin (control); G2=0.32 mg/kg; G3=1.68 mg/kg; G4=8.40 mg/kg of indomethacin.

Figure 1 - Maternal body weight ( $\mathrm{g}$ ) of female Wistar rats treated with indomethacin by intragastric administration (gavage) on days 3 and 4 of pregnancy. Values presented as mean $\pm \mathrm{SD}$.

$* \mathrm{p}<0.05$ - significant difference of G4 group compared to G1 group.

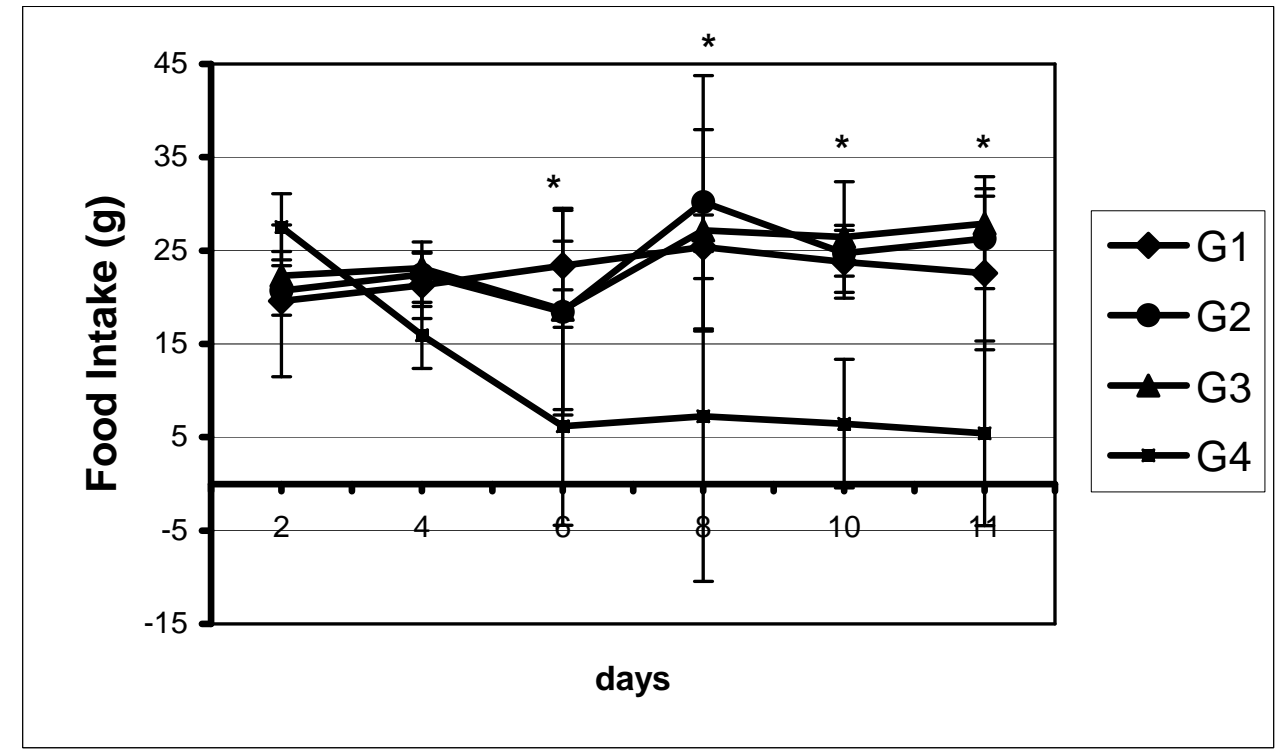

Legend: G1= $0 \mathrm{mg} / \mathrm{kg}$ of indomethacin (control); G2=0.32 mg/kg; G3=1.68 mg/kg; G4=8.40 mg/kg of indomethacin.

Figure 2 - Food intake (g) of female Wistar rats treated with indomethacin by intragastric administration (gavage) on days 3 and 4 of pregnancy. Values presented as mean \pm SD. $* \mathrm{p}<0.05$ - significant difference of G4 group compared to G1 group. 
Table 1 - Reproductive performance data of Wistar rats given indomethacin by intragastric administration (gavage) on days 3 and 4 of pregnancy.

\begin{tabular}{|c|c|c|c|c|}
\hline Dose (mg/kg) & $\begin{array}{c}\text { G1 } \\
0 \text { (control) }\end{array}$ & $\begin{array}{c}\mathrm{G2} \\
0.32 \mathrm{mg} / \mathrm{kg}\end{array}$ & $\begin{array}{c}\mathrm{G3} \\
1.68 \mathrm{mg} / \mathrm{kg}\end{array}$ & $\begin{array}{c}\mathrm{G} 4 \\
8.40 \mathrm{mg} / \mathrm{kg}\end{array}$ \\
\hline \multicolumn{5}{|l|}{ No. of females } \\
\hline Mated & 10 & 11 & 11 & 15 \\
\hline Pregnant at term & 10 & 11 & 11 & $11^{*}$ \\
\hline Maternal weight gain $(\mathrm{g})^{\mathrm{a}}$ & $45.33 \pm 11.36$ & $48.18 \pm 13.58$ & $42.55 \pm 6.27$ & $-35.64 \pm 17.25^{*}$ \\
\hline Corpora lutea number $^{\mathrm{a}}$ & $13.11 \pm 1.27$ & $13.36 \pm 1.56$ & $14.00 \pm 2.36$ & $12.27 \pm 1.10$ \\
\hline Implantation number ${ }^{\mathrm{a}}$ & $12.77 \pm 1.48$ & $12.64 \pm 1.21$ & $11.09 \pm 4.03$ & $10.63 \pm 2.61$ \\
\hline Embryos in development & $12.55 \pm 2.00$ & $12.64 \pm 1.21$ & $11.09 \pm 4.03$ & $10.54 \pm 2.54 *$ \\
\hline Preimplantation loss ${ }^{\mathrm{b}}$ & 2.60 & 5.0 & 11.46 & $14.47 *$ \\
\hline Postimplantation loss ${ }^{\mathrm{b}}$ & 2.22 & 0 & 0 & 0.69 \\
\hline Lethality Rate $^{\mathrm{b}}$ & $0 \%$ & $0 \%$ & $0 \%$ & $13.3 \% *$ \\
\hline Pregnancy Rate ${ }^{b}$ & $100 \%$ & $100 \%$ & $100 \%$ & $84.6 \%$ \\
\hline
\end{tabular}

\section{DISCUSSION}

The significant decrease in the body weight and food intake was evidenced as toxic sign in the rats given $8.40 \mathrm{mg} / \mathrm{kg}$ of the indomethacin during preimplantation period, indicating maternal toxicity. Administration of indomethacin at a dose of $8.40 \mathrm{mg} / \mathrm{kg}$ produced an increase in the preimplantation loss rate in the present study. There is evidence of involvement of the prostagladins (PG) in the first phase of the implantation, which resembles each other any inflammatory reaction (Van der Weiden et al., 1991). PG synthesis is increased at the implantation, perhaps in response to the blastocyst factors, such as the platelet-activating factor. The endometrial cells are also probable source of PG and this synthesis can be stimulated by the decidual reaction that accompanies the implantation (Harper, 1989). Many authors reported the role of $\mathrm{PG}$ on endometrium vascular permeability and on blastocyst implantation (Hamilton and Kennedy, 1994; Lim et al., 1997; Sookvanichsilp and Pulbutr, 2002). In rodents and rabbits, it was observed that the injection of PG inhibitors presented antiimplantational effect because it prevented an increased endometrial vascular permeability before embryonic implantation (Kennedy, 1987). In the present study, it was difficult to know whether antiimplantational effect occurred by $\mathrm{COX}-1$ or
COX-2 inhibition or both. A previous study suggested that inhibition of COX-2 alone could produce an inhibitory effect on blastocyst implantation, but inhibition of both COX-1 and COX-2 isoforms by indomethacin probably produced greater adverse effect on implantation (Sookvanichsilp and Pulbutr, 2002).

Morphological changes were not observed in the liver of the dams of the control and experimental groups (doses of 0.32 and $1.68 \mathrm{mg} / \mathrm{kg}$ ) in agreement to Rodrigues et al (1986). The microvacuolization of hepatocytes, a suggestive factor of cytoplasmic glycogen increase, the minimal inflammatory infiltrated in the portal triad, and binucleated hepatocyte increase verified at $8.40 \mathrm{mg} / \mathrm{kg}$ of indomethacin dose would be not associated to sign of hepatoxicity or hypersensibility of the drug.

The post mortem analysis showed that the pregnant rats that received $8.40 \mathrm{mg} / \mathrm{kg}$ presented peritonitis and ulcer formation in the colon with adherence to the epiplon, as also observed by other authors (Robert and Asano, 1977; Rodrigues et al., 1986; Yamagiwa et al., 2001). This could promote the embryonic implantation impairment, increasing the preimplantation loss. It was suggested that the damage especially caused by NSAID on the colon might be related with a higher number of bacteria in this intestinal segment in the monogastric herbivorous (e.g. rodents). Several prostaglandins and plant extract 
(Goulart et al., 2005) also protect the animals against the damages induced by indomethacin. There is hypothesis that certain prostaglandins may protect the mucosal membrane, creating a "cytoprotection" by preventing the spread of microorganisms and/or their toxins through the intestinal wall (Robert and Asano, 1977). In the present study, the microorganism culture study confirmed a growth of $E$. coli as much in the bacterial culture of the content of the peritonitis as of the intestinal content of the animals that received $8.40 \mathrm{mg} / \mathrm{kg}$ of indomethacin. This might be explained due the prostaglandin inhibition caused by the highest indomethacin dose, which appeared to weaken the resistance of the intestinal mucosa to E. coli and/or to their toxins. The latter might then cause cellular injury, which could destroy the integrity of the lining epithelium causing ulcers and gastroenteric perforations. In this way, the intestinal bacterial flora was translocated into the peritoneal cavity in the dams and caused peritonitis (Takahashi et al., 2001).

In conclusion, 0.32 and $1.68 \mathrm{mg} / \mathrm{kg}$ body weight (the therapeutic dose for humans) of indomethacin doses, a general COX inhibitor, did not cause embryotoxic or lethal effects. The highest dose $(8.40 \mathrm{mg} / \mathrm{kg})$ of indomethacin, given orally to rats on day 3-4 of pregnancy, disturbed implantation process and thus interrupted major development in some fetuses. The peritonitis detected in the necropsy and bacteriological study was the death cause of animals treated with $8.4 \mathrm{mg} / \mathrm{kg}$. Thus, this study analyzed a pharmacological agent on pregnancy in rodents and it provided some evidences that indomethacin presented embryotoxic and lethal effects at a high dose, but was safe in the therapeutic dose for the humans.

\section{ACKNOWLEDGMENTS}

The authors are grateful to Dr. Carlos Eduardo Meirelles dos Santos, Veterinary Center of Bauru, São Paulo State, Brazil, for necropsy of the animals; Profa. Dra. Ioshie Tanaka, Department of Microbiology, School of Medicine of Marília, São Paulo State, Brazil, for her collaboration in the microorganism culture study, and Profa. Dra. Teresa Cristina França Sartori and Marina F. Beirigo for liver morphological analysis.

\section{RESUMO}

O objetivo deste trabalho foi avaliar a performance reprodutiva, estudo morfológico do fígado e características "post mortem" de ratas Wistar prenhes tratadas com indometacina, um inibidor geral de COX. Indometacina foi administrada oralmente, nas doses de 0 (controle), 0,32, 1,68 e $8,40 \mathrm{mg} / \mathrm{kg} / \mathrm{dia}$ ( $\mathrm{n}=10 /$ grupo), nos dias 3 e $4 \mathrm{de}$ prenhez (dia $0=$ primeiro dia de prenhez $=$ esperma positivo). Os animais foram eutanasiados sob anestesia no $11^{\circ}$ dia de prenhez, e foram realizadas necropsia e cultura de microorganismos. Os resultados mostraram que as doses de $0,32 \mathrm{e}$ $1,68 \mathrm{mg} / \mathrm{kg}$ de peso corpóreo (dose terapêutica para humanos) de indometacina não causaram efeitos embriotóxicos ou letais. A maior dose $(8,40$ $\mathrm{mg} / \mathrm{kg}$ ) de indometacina prejudicou o processo de implantação e, portanto, interferiu no desenvolvimento fetal. A peritonite foi detectada na necropsia e nos estudos bacteriológicos dos animais tratados com $8,4 \mathrm{mg} / \mathrm{kg}$ e considerada a causa-morte destes animais. Portanto, este estudo analisou um agente farmacológico na prenhez de roedores e evidenciou que a indometacina apresentou efeitos embriotóxicos e letais na maior dose empregada, mas foi segura na dose terapêutica usada pelo homem.

\section{REFERENCES}

Chakraborty, I.; Das, S.K.; Wang, J. and Dey, S.K. (1996), Development expression of the cyclooxygenase- 1 and cyclo-oxygenase- 2 in the periimplantation mouse uterus and their differential regulation by the blastocyst and ovarian steroids. $J$. Mol. Endocrinol., 16, 107-122.

Clegg, E.D.; Perreault, S.D. and Klinefelter, G.R. (2001), Assessment of male reproductive toxicity. In: Hayes, A.W. ed. Principles and methods of toxicity. Philadelphia, Taylor and Francis, pp. 1263-1299.

Damasceno, D.C.; Volpato, G.T.; Person, O.C.; Yoshida, A.; Rudge, M.V.C. and Calderon, I.M.P. (2002), Efeito do ácido acetilsalicílico na performance reprodutiva e na prole de ratas Wistar. Rev. Assoc. Med. Bras., 48, 312-316.

Dannhardt, G. and Kiefer,W. (2001), Cyclooxygenase inhibitors-current status and future prospects. Eur. J. Med. Chem., 36, 109-126.

Goulart, Y.C.F.; Sela, V.R.; Obici, S.; Martins, J.V.C.; Otobone, F.; Cortez, D.A.; Audi, E.A. (2005). Evaluation of gastric and anti-ulcer activity in a hydro-ethanolic extract from Kielmeyera coriacea. Braz. Arch. Biol. Technol., 48, 211-216. 
Hamilton, G.G. and Kennedy, T.G. (1994), Uterine vascular changes after unilateral intrauterine infusion of indomethacin and prostaglandin $\mathrm{E}_{2}$ to rats sensitized for the decidual cell reaction. Biol. Reprod., 50, 757-764.

Harper, M.J.K. (1989), Platelet-activating factor: a paracrine factor in preimplantation stages of reproduction? Biol. Reprod., 40, 907-914.

Kennedy, T.G. (1977), Evidence for a role of prostaglandins in the initiation of blastocyst implantation in the rat. Biol. Reprod., 16, 286-291.

Kennedy, T.G. (1987), Interactions of eicosanoids and other factors in blastocyst implantation. In: Hiller, K. ed. Eicosanoids and reproduction. Norwell, MTP Press, pp. 73-88.

Lim H., Paria, B.C. and Das, S.K. (1997), Multiple female reproductive failure in cyclooxigenase-2 deficient mice. Cell., 91, 197-208.

Moore, K.L. and Persaud, P.V.N. (2005), Embriologia Clínica. Rio de Janeiro, Guanabara-Koogan.

Poyser, N.L. (1999), A comparasion of the effects of indomethacin and NS-398 (a selective prostaglandin $\mathrm{H}$ synthase-2 inhibitor) on implantation in the rat. Prostaglandins Leukot Essent Fatty Acids, 61, 297 301.

Robert, A. and Asano, T (1977), Resistance of germfree rats to indomethacin-induced intestinal lesions. Prostagl., 14, 333-341.

Rodrigues, J.R.P.; De Luca, L.A. and Macedo, A.R. (1986), Efeitos da indometacina sobre o fígado de ratas prenhes. Estudo experimental. J. Bras. Ginecol., 96, 145-149.

Salewski, E. (1964), Farbemethode zum markroskopishen nachweis von implantatconsstellen am uterus der ratter naunyn schmuderbergs. Arch. Pharmacol., 247, 367.
Shaquif, N.; Malhotra, S. and Pandhi, P. (2004), Comparison of nonseletive cyclo-oxygenase (COX) inhibitor and selective COX-2 inhibitors on preimplantation loss, postimpantation loss and duration of gestation: an experimental study. Contraception, 69, 71-75.

Sookvanichsilp, N. and Pulbutr, P. (2002), Antiimplantation effects of indomethacin and celecoxib in rats. Contraception, 65, 373-378.

Takahashi, H.; Ohno, N.; Adachi, Y. and Yadomae, T. (2001), Association of immunological disorders in lethal side effect of NSAIDS on beta-glucanadministered mice. FEMS Immunol. Med. Microbiol., 31, 1-14.

Tranguch, S.; Daikoku, T.; Guo, Y.; Wang, H. and Dey, S.K. (2005), Molecular complexity in establishing uterine receptivity and implantation. Cell. Mol. Life Sci., 62, 1964-1973.

Yamagiwa, S.; Yoshida, Y.; Halder, R.C.; Weerasinghe, A.; Sugahara, S.; Assakura, H. and Abo, T. (2001), Mechanisms involved in enteropathy induced by administration of nonsteroidal antiinflammatory drugs (NSAIDS). Digest. Dis. Sci., 46, 192-199.

Van der Weiden, R.M.F.; Helmerhorst, F.M. and Keirse, M.J.N.C. (1991), Influence of prostaglandins and platelet activating factor on implantation. Hum. Reprod., 6, 436.

Zar, J.H. (1999), Biostatistical analysis. New Jersey, Prentice-Hall.
Received: March 20, 2006; Revised: November 13, 2006; Accepted: July 24, 2007. 
PÁGINA

EM

BRANCO 